\title{
Faktor-Faktor yang Mempengaruhi Terjadinya Asfiksia pada Bayi Baru Lahir (BBL) di Wilayah Kerja Puskesmas Sibreh
}

\author{
Factors Affecting the Occurrence of Asphyxia in Newborns (BBL) in the \\ Territory of Sibreh Health Center \\ Asmaul Husna ${ }^{* 1}$, Evi Salmala ${ }^{2}$, Marniati ${ }^{3}$, Nuzulul Rahmi ${ }^{4}$ \\ ${ }^{1,2}$ Program Studi D-IV Kebidanan, Fakultas Ilmu Kesehatan, Universitas Ubudiyah Indonesia, Jl. Alue Naga \\ Desa Tibang Kota Banda Aceh \\ ${ }^{3}$ Program Studi S1 Ilmu Kesehatan Masyarakat, Fakultas Ilmu Kesehatan, Universitas Ubudiyah Indonesia, J1. Alue Naga \\ Desa Tibang Kota Banda Aceh \\ ${ }^{4}$ Program Studi D-III Kebidanan, Fakultas Ilmu Kesehatan, Universitas Ubudiyah Indonesia, Jl. Alue Naga \\ Desa Tibang Kota Banda Aceh \\ *Korespondensi Penulis: asmaulhusna@uui.ac.id
}

\begin{abstract}
Abstrak
Angka kematian bayi merupakan salah satu indikator dalam menentukan derajat kesehatan anak. Setiap tahun kematian bayi baru lahir atau neonatal mencapai 37\% dari semua kematian pada anak balita. Setiap hari 8.000 bayi baru lahir di dunia meninggal dari penyebab yang tidak dapat dicegah. Mayoritas dari semua kematian bayi, sekitar $75 \%$ terjadi pada minggu pertama kehidupan dan antara $25 \%$ sampai $45 \%$ kematian tersebut terjadi dalam 24 jam pertama kehidupan seorang bayi. Penyebab utama kematian bayi baru lahir atau neonatal di dunia antara lain bayi lahir premature 29\%, sepsis dan pneumonia 25\% dan 23\% merupakan bayi lahir dengan asfiksia dan trauma, asfiksia lahir menempati penyebab kematian bayi ke 3 di dunia dalam periode awal kehidupan (WHO, 2012). Berdasarkan hasil penelitian yang telah dilakukan maka penelitian dapat menyimpulkan hasil dari penelitian sebagai berikut Ada pengaruh yang singnifikan antara berat badan lahir rendah (BBLR) dengan terjadinya asfiksia pada bayi baru lahir Di Wilayah Kerja Puskesmas Sibreh dengan nilai $p \leq 0,05$ $(0,002)$ Ada pengaruh yang singnifikan antara usia ibu dengan terjadinya asfiksia pada bayi baru lahir Di Wilayah Kerja Puskesmas Sibreh dengan nilai $p \leq 0,05(0,015)$ Ada pengaruh yang singnifikan antara usia kehamilan dengan terjadinya asfiksia pada bayi baru lahir Di Wilayah Kerja Puskesmas Sibreh dengan nilai $\mathrm{p} \leq 0,05(0,022)$
\end{abstract}

Kata kunci : berat badan, usia ibu, usia kehamilan

\begin{abstract}
The infant mortality rate is one indicator in determining the child's health status. Every year newborn or neonatal deaths reach $37 \%$ of all deaths in children under five. Every day 8,000 newborns in the world die from preventable causes. The majority of all infant deaths, around $75 \%$, occur in the first week of life and between $25 \%$ and $45 \%$ of these deaths occur within the first 24 hours of a baby's life. The main causes of newborn or neonatal deaths in the world include premature babies $29 \%$, sepsis and pneumonia $25 \%$ and $23 \%$ are babies born with asphyxia and trauma, birth asphyxia occupies the third cause of infant mortality in the world in the early period of life (WHO , 2012). Based on the results of research that has been done, the study can conclude the results of the study as follows. There is a significant
\end{abstract}


influence between low birth weight (LBW) and the occurrence of asphyxia in newborns in the Sibreh Health Center Work Area with a $p$ value of 50.05 (0.002). significant influence between the age of the mother with the occurrence of asphyxia in newborns in the Sibreh Health Center Work Area with a $p$ value of $\leq 0.05$ (0.015) There is a significant influence between gestational age and the occurrence of asphyxia in newborns in the Sibreh Health Center Work Area with $p \leq 0.05$ (0.022)

Keywords: body weight, mother's age, gestational age

\section{PENDAHULUAN}

Angka kematian bayi merupakan salah satu indikator dalam menentukan derajat kesehatan anak. Setiap tahun kematian bayi baru lahir atau neonatal mencapai 37\% dari semua kematian pada anak balita. Setiap hari 8.000 bayi baru lahir di dunia meninggal dari penyebab yang tidak dapat dicegah. Mayoritas dari semua kematian bayi, sekitar $75 \%$ terjadi pada minggu pertama kehidupan dan antara 25\% sampai $45 \%$ kematian tersebut terjadi dalam 24 jam pertama kehidupan seorang bayi. Penyebab utama kematian bayi baru lahir atau neonatal di dunia antara lain bayi lahir premature 29\%, sepsis dan pneumonia $25 \%$ dan $23 \%$ merupakan bayi lahir dengan asfiksia dan trauma, asfiksia lahir menempati penyebab kematian bayi ke 3 di dunia dalam periode awal kehidupan (WHO, 2012).

Angka kematian bayi merupakan salah satu indikator dalam menentukan derajat kesehatan anak, angka kematian bayi terutama pada masa neonatal masih cukup tinggi dan menjadi masalah kesehatan baik secara global, regional maupun di Indonesia. Itulah sebab nya tujuan keempat Millennium Development Goals( MDGs) adalah mengurangi jumlah kematian anak (Haider dan Bhutta, 2006).

Asfiksia neonatorum merupakan keadaan bayi yang tidak bisa bernapas spontan dan teratur sehingga dapat menurunkan $\mathrm{O} 2$ dan makin meningkat nya $\mathrm{CO} 2$ yang dapat menimbulkan keadaan buruk pada kehidupan bayi lebih lanjut. Untuk mengurangi hal tersebut maka perlu melakukan tindakan terhadap bayi asfiksia tidak bereaksi terhadap rangsangan dan tidak akan menunjukan upaya pernapasan secara spontan, kematian akan terjadi kecuali dilakukan segera tindakan resusitasi dengan pernapasan buatan dan pemberian oksigen dengan segera (Saifuddin, 2006).

Penyebab langsung kematian bayi di Indonesia diantara nya disebabkan oleh asfiksia (44-46\%), infeksi ( $24-25 \%$ ), BBLR ( $15-20 \%$ ), trauma persalinan ( 2-7\% ) dan cacat 
bawaan (1- 3\%). Semua kematian bayi dan anak hasil SDKI 2012 lebih rendah dari SDKI 2007.untuk periode lima tahun sebelum survey, angka kematian bayi hasil SDKI 2012 adalah 32 kelahiran per 1000 kelahiran hidup dan kematian balita adalah 40 kematian per 1000 kelahiran hidup. sama dengan pola SDKI 2007, lebih dari tiga perempat dari semua kematian balita terjadi dalam tahun pertama kehidupan anak dan mayoritas kematian bayi terjadi pada periode neonatus.

Di indonesia Angka Kematian Bayi (AKB) pada tahun 2009 tercatat 26/1000 kelahiran hidup sedangkan tahun 2010 tercatat 34/1000 kelahiran hidup.Angka Kematian di Indonesia dari tahun ketahun semakin meningkat hal ini disebabkan oleh beberapa faktor yakni salah satu diantaranya disebabkan karena asfiksia neonatorum. Kejadian Asfiksia di Indonesia mencapai 13\% per 1000 kelahiran. Hal ini di pengaruhi oleh ibu yang memiliki ekonomi rendah karena ibu yang ekonomi rendah sering kali tidak memeriksa kehamilan nya ditenaga kesehatan begitu pun pada saat persalinan sehingga ibu tidak mendapatkan pelayanan persalinan yang aman dan baik, (Depkes RI,2010).

\section{METODE PENELITIAN}

Penelitian ini menggunakan jenis penelitian yang bersifat survey analitik dengan desain cross-sectional. Populasi dalam penelitian ini adalah seluruh bayi yang mengalami asfiksia yang berjumlah 94 bayi di rumah sakit ibu dan anak dari bulan Desember sampai dengan bulan Januari 2017. Pengambilan sampel dalam penelitian dilakukan secara total populasi, yaitu dengan cara menetapkan semua sebanyak 94 bayi sebagai sampel., Tempat dan waktu penelitian ini dilaksanakan di Wilayah Kerja Puskesmas Sibreh pada bulan Januari tahun 2017. Analisis univariat bertujuan untuk menjelaskan atau mendeskripsikan karakteristik setiap variabel penelitian. Pada analisis univariat peneliti hanya melihat distribusi frekuensi dan persentase setiap variabel yang diteliti yaitu kejadian diare, pengetahuan dan sikap ibu. Analisis bivariat pada penelitian ini menggunakan uji statistik chi square, dengan batas kemaknaan $(\alpha=0,05)$ atau Confident Level $(\mathrm{CL})=95 \%$. Diolah dengan menggunakan komputerisasi. Untuk analisa bivariat pada penelitian ini adalah melihat hubungan antara pengetahuan, sikap dengan kejadian diare pada balita. Nilai yang dilihat untuk mengetahui kedua variabel ada hubungan adalah dengan nilai $\mathrm{p}<0,05$. 


\section{HASIL DAN PEMBAHASAN}

Tabel 1. Pengaruh Berat Badan Lahir Rendah (BBLR) Dengan Terjadinya Asfiksia Pada Bayi Baru Lahir Di Wilayah Kerja Puskesmas Sibreh

\begin{tabular}{|c|c|c|c|c|c|c|c|c|c|c|}
\hline \multirow{3}{*}{ No } & \multirow{3}{*}{ BBLR } & \multicolumn{6}{|c|}{$\begin{array}{c}\text { Terjadi Asfiksia Pada Bayi } \\
\text { Baru Lahir }\end{array}$} & \multirow{2}{*}{\multicolumn{2}{|c|}{ Total }} & \multirow{3}{*}{$\begin{array}{c}\text { P- } \\
\text { Value }\end{array}$} \\
\hline & & \multicolumn{2}{|c|}{ Berat } & \multicolumn{2}{|c|}{ Sedang } & \multicolumn{2}{|c|}{ Ringan } & & & \\
\hline & & $\mathbf{f}$ & $\%$ & $\mathbf{f}$ & $\%$ & f & $\%$ & f & $\%$ & \\
\hline 1 & $\mathrm{Ya}$ & 20 & 48,8 & 12 & 29,3 & 9 & 22 & 41 & 100 & \\
\hline 2 & Tidak & 9 & 17 & 33 & 62,3 & 11 & 20,8 & 53 & 100 & 0,002 \\
\hline
\end{tabular}

Berdasarkan tabel 4.5 diatas dapat dilihat bahwa dari 41 responden kejadian asfiksia pada bayi baru lahir berat mayoritas terjadi pada bayi BBLR yaitu sebanyak 20 responden $(48,8 \%)$, sedangkan dari 53 responden kejadian asfiksia pada bayi baru lahir sedang mayoritas bayi tidak BBLR yaitu sebanyak 33 responden $(62,3 \%)$.

Selanjutnya dari analisa menggunakan chi square $\left(X^{2}\right)$ dengan tingkat kemaknaan $(\alpha)$ adalah $\leq$ 0,05 didapatkan nilai Probabilitas ( $p$ ) 0,002. Sehingga dapat disimpulkan bahwa ada pengaruh yang singnifikan antara berat badan lahir rendah (bblr) dengan terjadinya asfiksia pada bayi baru lahir Di Wilayah Kerja Puskesmas Sibreh.

Tabel 2. Pengaruh Usia Ibu dengan Terjadinya Asfiksia pada Bayi Baru Lahir di Wilayah Kerja Puskesmas Sibreh

\begin{tabular}{|c|c|c|c|c|c|c|c|c|c|c|}
\hline \multirow{3}{*}{ No } & \multirow{3}{*}{ Usia Ibu } & \multicolumn{6}{|c|}{$\begin{array}{c}\text { Kejadian Asfiksia Pada Bayi } \\
\text { Baru Lahir }\end{array}$} & \multirow{2}{*}{\multicolumn{2}{|c|}{ Total }} & \multirow{3}{*}{$\begin{array}{c}P- \\
\text { Value }\end{array}$} \\
\hline & & \multicolumn{2}{|c|}{ Berat } & \multicolumn{2}{|c|}{ Sedang } & \multicolumn{2}{|c|}{ Ringan } & & & \\
\hline & & f & $\%$ & f & $\%$ & f & $\%$ & $\mathbf{f}$ & $\%$ & \\
\hline 1 & Beresiko & 20 & 45,5 & 16 & 36,4 & 8 & 18,2 & 44 & 100 & \\
\hline 2 & $\begin{array}{l}\text { Tidak } \\
\text { beresiko }\end{array}$ & 9 & 18 & 29 & 58 & 12 & 24 & 50 & 100 & 0,015 \\
\hline
\end{tabular}

Berdasarkan tabel 4.6 diatas dapat dilihat bahwa dari 44 responden kejadian asfiksia pada bayi baru lahir berat mayoritas terjadi pada pada ibu usia ibu beresiko yaitu sebanyak 
20 responden $(45,5 \%)$, sedangkan dari 51 responden kejadian asfiksia pada bayi baru lahir sedang mayoritas terjadi pada usia tidak bersiko sebanyak 29 responden (58\%).

Selanjutnya dari analisa menggunakan chi square $\left(X^{2}\right)$ dengan tingkat kemaknaan $(\alpha)$ adalah $\leq$ 0,05 didapatkan nilai Probabilitas ( $p$ ) 0,015. Sehingga dapat disimpulkan bahwa ada pengaruh yang singnifikan antara usia ibu dengan terjadinya asfiksia pada bayi baru lahir Di Wilayah Kerja Puskesmas Sibreh.

\section{Pembahasan}

1. Pengaruh Berat Badan Lahir Rendah (BBLR) Dengan Terjadinya Asfiksia Pada Bayi Baru Lahir

Berdasarkan hasil penelitian yang telah dilakukan menunjukkan bahwa dari 44 responden kejadian asfiksia pada bayi berat baru lahir berat mayoritas terjadi pada pada ibu usia ibu beresiko yaitu sebanyak 20 responden (45,5\%), sedangkan dari 51 responden kejadian asfiksia pada bayi baru lahir sedang mayoritas terjadi pada usia tidak bersiko sebanyak 29 responden $(58 \%)$.

Selanjutnya dari analisa menggunakan chi square $\left(X^{2}\right)$ dengan tingkat kemaknaan $(\alpha)$ adalah $\leq 0,05$ didapatkan nilai Probabilitas $(p)$ 0,015. Sehingga dapat disimpulkan bahwa ada pengaruh yang singnifikan antara usia ibu dengan terjadinya asfiksia pada bayi baru lahir Di Wilayah Kerja Puskesmas Sibreh.

Hasil penelitian ini sesuai dengan penelitian yang telah dilakukan oleh Gilang (2012), yang berjudul "Faktor- Faktor Yang Berhubungan Dengan Kejadian Asfiksia Neonatorum Studi Di RSUD Tugurejo Semarang” hasil analisis bivariat didapat hasil Fisher's Exact yang sudah dilakukan koreksi didapat p-value sebesar 0,001 (<0.05), yang berarti menunjukan bahwa ada pengaruh antara berat badan lahir bayi dengan kejadian asfiksia.

Bayi berat lahir rendah (BBLR) Ialah bayi baru lahir yang berat badannya saat lahir kurang dari 2.500 gram (sampai dengan 2.499 gram) (prawiro hardjo dalam rukiyah. 2010), sedangkan sejak tahun 1961 WHO dalam yeyeh 2010 telah mengantikan istilah premature dengan bayi berat badan lahir rendah (BBLR). hal ini dilakukan karena tidak semua bayi yang berat kurang dari 2.500 gram pada waktu lahir adalah bayi prematur (Rukiyah, 2010). 
Menurut asumsi peneliti menunjukkan bahwa ada pengaruh antara Berat Badan Lahir Rendah (BBLR) Dengan Terjadinya Asfiksia Pada Bayi Baru Lahir, Bayi dengan berat badan lahir rendah kurang dari 2500 gram dikarenakan bayi baru lahir berisiko mengalami kematian perinatal sebab fungsi alat-alat tubuhnya belum lengkap dan sempurna. Kondisi tubuh yang tidak stabil pada BBLR cenderung akan mengalami kehidupan masa depan yang kurang baik dibandingkan dengan bayi yang lahir dengan berat badan $\geq 2500$ gram.

2. Pengaruh Usia Ibu dengan Terjadinya Asfiksia Pada Bayi Baru Lahir

Berdasarkan hasil penelitian yang telah dilakukan menujukkan bahwa dari 44 responden kejadian asfiksia pada bayi baru lahir berat mayoritas terjadi pada pada ibu usia ibu beresiko yaitu sebanyak 20 responden (45,5\%), sedangkan dari 51 responden kejadian asfiksia pada bayi baru lahir sedang mayoritas terjadi pada usia tidak bersiko sebanyak 29 responden $(58 \%)$.

Selanjutnya dari analisa menggunakan chi square $\left(X^{2}\right)$ dengan tingkat kemaknaan $(\alpha)$ adalah $\leq$ 0,05 didapatkan nilai Probabilitas $(p)$ 0,015. Sehingga dapat disimpulkan bahwa ada pengaruh yang singnifikan antara usia ibu dengan terjadinya asfiksia pada bayi baru lahir Di Wilayah Kerja Puskesmas Sibreh.

Hasil penelitian ini sesuai dengan penelitian yang telah dilakukan oleh Rika, (2012) yang berjudul tentang Faktor - Faktor yang Menyebabkan Terjadinya Asfiksia Neonatorum Pada Bayi Baru Lahir Di Rumah Sakit Umum Daerah Kabupaten Rokan Hulu. Dari hasil analisis statistik diperoleh nilai $\mathrm{p}$ value $=0,001$. Dari nilai tersebut dapat diketahui bahwa $\mathrm{p}$ value $<0,05$ yang berarti bahwa tada hubungan yang signifikan antara usia ibu dengan kejadian Asfiksia Neonatorum.

Umur muda (< 20 tahun) beresiko karena ibu belum siap secara medis (organ reproduksi) maupun secara mental. Hasil penelitian menunjukan bahwa primiparity merupakan faktor resiko yang mempunyai hubungan yang kuat terhadap mortalitas asfiksia, sedangkan umur tua (> 35 tahun), secara fisik ibu mengalami kemunduran untuk menjalani kehamilan. Keadaan tersebut memberikan predisposisi untuk terjadi perdarahan, plasenta previa, rupture uteri, solutio plasenta yang dapat berakhir dengan terjadinya asfiksia bayi baru lahir (Manuaba, 2010). 
Umur biasa secara langsung berpengaruh terhadap kejadian Asfiksia. Pertambahan umur disertai dengan organ-organ dalam rongga pelvis.pada wanita muda $(<20$ tahun $)$ organ-organ belum sempurna secara keseluruhan disertai dengan kejiwaan yang belum bersedia menjadi ibu, keadaan ini akan mempengaruhi keadaan janin dan rahim. Sedangkan pada usia di atas 35 tahun fungsi reproduksi seorang wanita sudah mengalami penurunan dibandingkan fungsi reproduksi normal (Martaasoebrata,1992). Faktor ibu yang dapat menyebabkan terjadinya asfiksia neonatorum adalah hipoksia,usia kurang dari 20 tahun atau lebih dari 35 tahun (Nur, wafi,2011).

Menurut asumsi peneliti menujukkan bahwa ada pengaruh antara usia ibu dengan terjadinya asfiksia pada bayi baru lahir, usia ibu saat hamil sangat dipengaruhi oleh keadaan kehamilan yang berlanjut, pada kehamilan karena dengan umur ibu $<20$ tahun alat reproduksi belum dapat berproduksi dengan sempurna, akan sangat beresiko disaat melahirkan mengalami cacat. Sedangkan ibu hamil yang berusia $>35$ tahun memilki organ reproduksi yang lebih lemah karena sudah terjadi penuan. Ibu dengan kategori umur berisiko ( $<20$ tahun dan/atau $>35$ tahun) menyebabkan lebih banyak terjadinya asfiksia daripada ibu dengan kategori umur tidak berisiko 20-35 tahun.

\section{KESIMPULAN}

Berdasarkan hasil penelitian yang telah dilakukan maka penelitian dapat menyimpulkan hasil dari penelitian sebagai berikut :

1. Ada pengaruh yang singnifikan antara berat badan lahir rendah (BBLR) dengan terjadinya asfiksia pada bayi baru lahir Di Wilayah Kerja Puskesmas Sibreh dengan nilai $\mathrm{p} \leq 0,05$ $(0,002)$.

2. Ada pengaruh yang singnifikan antara usia ibu dengan terjadinya asfiksia pada bayi baru lahir Di Wilayah Kerja Puskesmas Sibreh dengan nilai $\mathrm{p} \leq 0,05(0,015)$.

\section{SARAN}

Di harapkan dapat membantu penurunan angka kematian bayi yaitu dengan ada nya peningkatan pengetahuan pemahaman tentang faktor-faktor yang mempengaruhi terjadinya asfiksia pada bayi baru lahi dan diharapkan agar dapat memeriksakan kehamilan nya, dengan 
memamfaatkan fasilitas kesehatan yang tersedia untuk memperkecil kemungkinan penyebab terjadinya asfiksia.

\section{DAFTAR PUSTAKA}

Depkes RI . (2013). Asuhan Persalinan Normal .Jakarta, Depkes RI

Depkes RI . (2010). Asuhan Persalinan Normal .Jakarta, Depkes RI

Fauziah, Afroh. (2013). Buku Asuhan Neonatus Resiko Tinggi dan Kegawatan Yogyakarta.Nuha Medika.

Haider dan bhutta.( 2006 ). Birth Asphyxia in Developing countries : Current Status And Public Health Inplications. Pakistan : Curr Probl Pediatr Adolesc Health Care

Hakimi , M. (2009). Fisiologi dan patologi persalinan (terjemahan). Jakarta :Yayasan Essensia Medika.

Lestari, (2009), Penyebab dan Dampak KPD, Cermin Dunia Kedoktoran, (Online), Available.(http://ww.Kalbefarma.com/files/cdk.12 maret 2015

Lukman, (2010), Menurunkan Angka KPD htt://www. selatan. Jakarta. Go.id/pkk/index.php diakses pada tanggal 12 maret 2015.

Manuaba, Ide AyuChandranita, dkk. (2010). Ilmu Kebidanan Penyakit Kandungan, dan KB untuk pendidikan Bidan. Jakarta : EGC

Manuaba IBG. (2002). ilmu Kebidanan, Penyakit Kandungan Dan Keluarga Berencana Untuk Pendidikan Bidan. Jakarta. EGC

Muazizah. (2011). Hubungan Antara Kadar Hemoglobin Ibu Hamil Dengan Berat Bayi Lahir Di RS Permata Bunda Kabupaten Globongan Skripsi. Universitas muhammadiyah semarang.

Notoatmodjo, (2005).Metode PENELITIAN Kesehatan.Jakarta :Rineka Cipta .

Proverawati. A Wati.2011.Ilmu Gizi Untuk Keperawatan dan Gizi Kesehatan, Cetakan Kedua, Penerbit Muha Medika Yogyakarta.

Nur, Wafi. (2011).Asuhan Neonatus Bayi Dan Balita, Edisi 3, Yogyakarta.Fitra Maya.

Pantiawati, Ika. (2010). Buku Bayi dengan BBLR.Yogyakarta.Nuha Medika.

Proverawati, A, danIsmawati, C, (2010).BBLR, Berat Badan Lahir Rendah : Yogyakarta, Nuha Medika.

Rochmah dkk, ( 2012).Buku Asuhan Neonatus, Bayi, dan Balita.JAKARTA, Buku Kedoktoran EGC.

Sarwono, (2010). Buku Asuhan Neonatus, Bayi dan Balita, Jakarta, CV. Teans Info Media 
Surve Demografi dan Kesehatan Indonesia. Laporan pendahuluan SDKI (2012).http://www.bkkbn..go.id/litbang/pusdu/hasil\%20penelitian/SDKI\%202012/lapor an\%20pendahuluan \%20SDKI\%202012.pdf

Saiffudin,( 2006).BukuAcuan :AsuhanPersalinan Normal. Jakarta. Penerbit Buku Kedoktoran EGC.

Sukarni, lcesmi dan sudarti. (2014). Buku Patologi Kehamilan, Persalinan, Nifas Dan Neonatus Resiko Tinggi. Yogyakarta, NuhaMedika.

Sumarah, R. ( 2009 ). Survei AKI dan AKB di Indonesia. Varney, Helen. 2007. Buku Ajar Asuhan Kebidanan. Edisi 4, Jakarta Penerbit Buku Kedoktoran EGC.

Yeyeh, Rukiyah, Ai danYulianti, Lia. (2010). Buku Asuhan Neonatus, Bayi dan Balita, Jakarta, CV. Teans Info Media 